\title{
Five-Years Tigecycline Experience an Analysis of Real-Life Data
}

\author{
Beş Yıllık Tigesiklin Deneyimi Gerçek Yaşam Verilerinin Bir Analizi

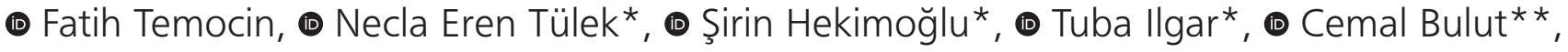 ๑ Fatma Şebnem Erdinç*, ๑ Günay Tuncer Ertem*, ๑ Çiğdem Ataman Hatipoğlu*, \\ (1) Sami Kınıklı*
}

Yozgat City Hospital, Clinic of Infectious Diseases and Clinical Microbiology, Yozgat, Turkey

${ }^{*}$ Ankara Training and Research Hospital, Clinic of Infectious Diseases and Clinical Microbiology, Ankara, Turkey

${ }^{*}$ Kırıkkale University Faculty of Medicine, Depatment of Infectious Diseases and Clinical Microbiology, Kırıkkale, Turkey

\begin{abstract}
Aim: Tigecycline has been approved by the Food and Drug Administration for the treatment of complicated intra-abdominal infections, skin and soft tissue infections and community-acquired pneumonia. In our study, we examined the efficacy of tigecycline in clinical practice and reported real life data from our hospital over a period of five years.
\end{abstract}

Methods: The study was conducted between 2008 and 2013 on patients who received tigecycline for longer than 48 hours in Ankara Training and Research Hospital. Clinical success was defined as clinical recovery and microbiological cure in patients who used tigecycline. Any reason for discontinuation of tigecycline treatment was considered a clinical failure.

Results: In our hospital, 320 patients were administered tigecycline between 2008 and 2013. Tigecycline was mainly used for pneumonia and skin and soft tissue infections. Tigecycline was used as monotherapy in 174 patients (54.1\%). The most frequently isolated agent in tigecycline-treated patients was Acinetobacter baumannii (43.4\%) followed by Enterococcus (6.9\%). A change in treatment was not considered necessary in 243 (75.9\%) patients who received tigecycline, while it was changed in 77 patients (24.1\%).

Conclusion: In conclusion, the use of tigecycline can be an effective treatment choice, either as monotherapy or as a combination antibiotic therapy.

Keywords: Tigecycline, real life data, minocycline
Öz

Amaç: Komplike intraabdominal enfeksiyonlar, deri ve yumuşak doku enfeksiyonları ve toplum kökenli pnömoni tedavisi için Tigesiklin kullanımına Gıda ve ilaç Dairesi tarafından onay verilmiştir. Çalışmamızda; beş yıllık süreçte hastanemiz bünyesinde tigesiklin kullanımının klinik pratikteki yeri irdelenmiş ve gerçek yaşam verileri sunulmuştur.

Yöntemler: Çalışma, 2008 ve 2013 yılları arasında, Ankara Eğitim ve Araştırma Hastanesi'nde, 48 saatten daha uzun süre ile tigesiklin kullanılan hastaların verileri retrospektif olarak değerlendirilmiştir. Klinik başarı, tigesiklini tek başına veya kombinasyonda kullanan hastaların tümünde klinik iyileşme ve mikrobiyolojik kür sağlanması olarak tanımlanmıştır. Herhangi bir nedenle tigesiklin tedavisinin kesilmesi klinik başarııızık olarak tanımlanmıştır.

Bulgular: Hastanemizde, 2008-2013 tarihleri arasında 320 hastaya tigesiklin kullanılmıştır. Tigesiklin en sık pnömoni ve deri-yumuşak doku enfeksiyonlarının tedavisinde kullanılmıştır. Hastaların 173'ünde $(\% 54,1)$ monoterapi olarak kullanılmıştır. Hastalarda en sık izole edilen etken Acinetobacter baumannii olup $(\% 43,4)$, ikinci sıklıkta Enterococcus izole edilmiştir $(\% 6,9)$. Tedavi alan hastaların 243 'ünde $(\% 75,9)$ tedavi değişikliğine gerek görülmemiş olup 77 hastada $(\% 24,1)$ tedavi değiştirilmiştir.

Sonuç: Sonuç olarak, çoğul dirençli bakteri enfeksiyonlarının tedavisinde, monoterapi ya da kombinasyon olarak kullanıldığında tigesiklin bir seçenek olarak düşünülmelidir.

Anahtar Sözcükler: Tigesiklin, gerçek yaşam verisi, minosiklin

\section{Introduction}

Tigecycline, a derivative of minocycline, is the first glycylcycline antibiotic approved by the US Food and
Drug Administration (FDA). It shows structural similarities to tetracycline. Tigecycline reversibly binds to the $30 \mathrm{~S}$ ribosomal subunit and thereby inhibits protein synthesis
Address for Correspondence/Yazışma Adresi: Fatih Temocin

Yozgat City Hospital, Clinic of Infectious Diseases and Clinical Microbiology, Yozgat, Turkey

Phone: +90 5058410348 E-mail: ftemucin@yahoo.com.tr ORCID ID: orcid.org/0000-0002-4819-8242

Received/Geliş Tarihi: 16 July 2017 Accepted/Kabul Tarihi: 09 November 2017
${ }^{\circ}$ Copyright 2018 by The Medical Bulletin of University of Health Sciences Haseki Training and Research Hospital
The Medical Bulletin of Haseki published by Galenos Yayınevi.

${ }^{\circledR}$ Telif Hakkı 2018 Sağlık Bilimleri Üniversitesi Haseki Eğitim ve Araştırma Hastanesi Haseki Tıp Bülteni, Galenos Yayınevi tarafindan basılmışıır. 
$(1,2)$. This drug can bypass the two significant resistance mechanisms of tetracycline. The first one is the tetracyclinespecific efflux pump mechanism, for which tigecycline serves as a poor substrate. The second resistance mechanism is the Tet(M) protein-mediated modification that inhibits binding of tetracycline, but allows binding of tigecycline to the bacterial ribosomes (3).

Tigecycline is bacteriostatic in nature; however, reports of bactericidal activity have been demonstrated against certain microorganisms $(4,5)$. It has a broad clinical spectrum of activity against many gram-negative bacteria such as those of Enterobacteriaceae family, including extended-spectrum-beta-lactamase-producing Enterobacteriaceae, and against many multi-drug resistant strains of Gram-positive bacteria such as methicillinresistant Staphylococcus aureus and Staphylococcus epidermidis, penicillin-resistant Streptococcus pneumonia and vancomycin-resistant Enterococcus. Also, tigecycline has an improved activity in vitro against Enterobacter, Acinetobacter and Stenotrophomonas maltophilia strains. However, it has no in vitro efficiency against Proteus spp., Providencia spp. and non-fermentative Pseudomonas aeruginosa. Tigecycline is very effective against anaerobic bacteria such as Bacteroides spp., including B. fragilis, B. Thetaiotaomicron and $B$. Uniformis, with some exceptions like Clostridium perfringens and Clostridium difficile (610).

Tigecycline has been approved by the FDA for the treatment of complicated intra-abdominal infections, skin and soft tissue infections and community-acquired pneumonia $(11,12)$. However, information concerning the role of tigecycline in community-acquired pneumonia, ventilator-associated pneumonia, urinary infections, central nervous system infections, and bone infections is limited.

In our study, we examined the efficacy of tigecycline in clinical practice and reported real life data from our hospital over a period of five years.

\section{Methods}

A retrospective study was conducted by the department of infectious diseases and clinical microbiology at a 650bed training and research hospital in Ankara, located in the capital city of Turkey. The study was conducted between

\begin{tabular}{|c|c|c|c|}
\hline Patient demographics & Total population & $\begin{array}{l}\text { Patients with treatment } \\
\text { on ICU }\end{array}$ & $\begin{array}{l}\text { Patients with treatment } \\
\text { outside ICU }\end{array}$ \\
\hline & 320 & 163 & 157 \\
\hline \multicolumn{4}{|l|}{ Demographic characteristics } \\
\hline Male, \% (n) & $47.5 \%(152)$ & $46.0 \%(75)$ & $49.0 \%(77)$ \\
\hline Age, mean years \pm SD (range) & $59.5 \pm 19.2(17-97)$ & $62.9 \pm 19.8(18-97)$ & $56.1 \pm 18(17-95)$ \\
\hline \multicolumn{4}{|l|}{ Clinical characteristics } \\
\hline Duration of tigecycline therapy & $10.6 \pm 6.6$ days (range, 2-35). & $10.87 \pm 7$ days (range, 2-35) & $10.5 \pm 6.5$ days (range, $2-30$ ) \\
\hline Empiric use \% (n) & $35.6 \%(114)$ & $25.8 \%(42)$ & $45.9 \%(72)$ \\
\hline Combination of antibiotics, \% (n) & $45.9 \%(147)$ & $59.5 \%(97)$ & $31.8 \%(50)$ \\
\hline \multicolumn{4}{|l|}{ Type of infections } \\
\hline Community-acquired pneumonia & $4.6 \%(15)$ & $6.1 \%(10)$ & $3.1 \%(5)$ \\
\hline Hospital-acquired pneumonia & $25 \%(80)$ & $47.8 \%(78)$ & $1.2 \%(2)$ \\
\hline Complicated skin and soft tissue infection & $25 \%(80)$ & $8.6 \%(14)$ & $42.0 \%(66)$ \\
\hline Intraabdominal infection & $14.7 \%(47)$ & $11.0 \%(18)$ & $18.5 \%(29)$ \\
\hline Surgical site infections & $10.0 \%(32)$ & $5.5 \%(9)$ & $14.6 \%(23)$ \\
\hline Urinary tract infestion & $9.4 \%(30)$ & $9.8 \%(16)$ & $8.9 \%(14)$ \\
\hline Intravascular catheter-related infections & $4.4 \%(14)$ & $6.1 \%(10)$ & $2.5 \%(4)$ \\
\hline Osteomyelitis & $3.8 \%(12)$ & $0.0 \%(0)$ & $7.6 \%(12)$ \\
\hline Blood stream infection & $1.6 \%(5)$ & $2.5 \%(4)$ & $0.6 \%(1)$ \\
\hline Meningitis & $0.9 \%(3)$ & $1.2 \%(2)$ & $0.6 \%(1)$ \\
\hline Prosthetic joint infections & $0.6 \%(2)$ & $0.0 \%(0)$ & $1.3 \%(2)$ \\
\hline
\end{tabular}


2008 and 2013 on patients who received tigecycline for longer than 48 hours in the hospital. All patients in the study received tigecycline doses recommended by the FDA (an initial loading dose of $100 \mathrm{mg}$, followed by $50 \mathrm{mg}$ administered intravenously every 12 hours). All data were acquired by scanning the hospital database and patient files. Patients' age, gender, ward type (clinic or intensive care), indication for tigecycline use, microbiological diagnosis, treatment modifications, combination antibiotic therapy, and clinical responses were recorded.

Clinical success was defined as clinical recovery and microbiological cure in patients who used tigecycline, alone or in combination. Any reason for discontinuation of tigecycline treatment was considered a clinical failure.

\section{Statistical Analysis}

Statistical analysis was performed with the Statistical Package for Social Sciences (SPSS) version 23 software program.

\section{Results}

In our hospital, 320 patients were administered tigecycline for more than 48 hours, between 2008 and 2013. Of these, 168 patients were female $(52.5 \%)$ and 152 patients were male (47.5\%). The average age of the patients was $59.6 \pm 19.22(19-97)$ years. The average duration of tigecycline treatment was $10.6 \pm 6.6$ days (235). The demographic and clinical characteristics of the patients and treatment indications are listed in Table 1.
Although tigecycline was mainly used for pneumonia indication, the other most common indications included complicated skin and soft tissue infections, and also intraabdominal infections (Table 2).

Indications for tigecycline use, duration of treatment and clinical response rates are given in the ratio of tigecycline use and clinical effectiveness, in intensive care and non-intensive care units, are given in Table 3.

Tigecycline was used as monotherapy in 174 patients $(54.1 \%)$, while it was used in combination with another antibiotic in 147 patients (45.9\%). The most preferred combination agents were aminoglycosides, and the most common indication for combination therapy was pneumonia. A list of preferred agents for combination therapy is shown in Table 4.

The most frequently isolated agent in tigecyclinetreated patients was Acinetobacter baumannii (43.4\%) followed by Enterococcus (6.9\%). In many cases, some form of the empirical treatments (36.6\%) was already started before the tigecycline treatment. The distribution of the isolated agents is shown in Table 5.

A change in treatment was not considered necessary in 243 (75.9\%) patients who received tigecycline, while the treatment was changed in 77 patients (24.1\%). This treatment change was due to unresponsiveness and side effects in $85.7 \%$ (66/77 and $20.6 \%$ of the total population) and $14.3 \%$ of the treated patients, respectively. Side effects that required treatment change were nausea/vomiting in 10 patients and an allergic reaction in one patient.

\begin{tabular}{|l|l|l|l|l|}
\hline Table 2. Type of infections, duration of treatment and clinical efficacy of tigecycline \\
\hline Type of infections & $\mathbf{n}(\%)$ & Duration of treatment days mean & Clinical efficacy $\mathbf{n}(\%)$ & Clinical failure $\mathbf{n}(\%)$ \\
\hline Hospital-acquired pneumonia & $80(25)$ & $11.6 \pm 7.0$ & $13(16.2)$ & $67(83.7)$ \\
\hline Community-acquired pneumonia & $15(4.6)$ & $7.1 \pm 5.7$ & $7(46.7)$ & $8(53.3)$ \\
\hline Complicated skin and soft tissue infections & $80(25)$ & $11 \pm 7.9$ & $50(62.5)$ & $30(37.5)$ \\
\hline Intraabdominal infections & $47(14.7)$ & $10.1 \pm 6.6$ & $28(59.5)$ & $19(40.5)$ \\
\hline Surgical site infections & $32(10)$ & $10.3 \pm 6.2$ & $23(71.8)$ & $9(28.2)$ \\
\hline Urinary tract infestion & $30(9.4)$ & $9.3 \pm 5.7$ & $15(50)$ & $15(50)$ \\
\hline Catheter infections & $14(4.4)$ & $9.2 \pm 7.3$ & $5(35.7)$ & $9(64.3)$ \\
\hline Osteomyelitis & $12(3.8)$ & $13.5 \pm 9.7$ & $9(75)$ & $3(25)$ \\
\hline Bloodstream infections & $5(1.6)$ & $17.6 \pm 3.7$ & $1(33.3)$ & $5(100)$ \\
\hline Meningitis & $3(0.9)$ & $7 \pm 2$ & $2(100)$ & $2(66.6)$ \\
\hline Prosthetic joint infections & $2(0.6)$ & $15.5 \pm 2.1$ & $153(47.8)$ & 0 \\
\hline Total & $320(100)$ & $10.6 \pm 6.6$ & $167(52.2)$ \\
\hline
\end{tabular}

Table 3. Duration of treatment and clinical efficacy of tigecycline according to type of unit

\begin{tabular}{|l|l|l|l|l|}
\hline Type of unit & $\mathbf{n}(\%)$ & Duration of treatment, days mean & Clinical efficacy $\mathbf{n}(\%)$ & Clinical failure $\mathbf{n}(\%)$ \\
\hline Intensive care unit & $163(50.9)$ & $10.8 \pm 6.9$ & $34(20.9)$ & $129(79.1)$ \\
\hline Non- intensive care unit & $157(49.1)$ & $10.4 \pm 6.4$ & $119(75.8)$ & $38(24.2)$ \\
\hline
\end{tabular}




\section{Discussion}

In this analysis, we presented real life data of 320 patients who received tigecycline over a five-year period. Tigecycline is used for many indications other than those approved by the FDA. The rate of tigecycline use was 54.3\% for the FDA approved indications, namely complicated skin and soft tissue infections (including surgical site infection), complicated intra-abdominal infections, and communityacquired pneumonia. Skin and soft tissue infections were the most common among these indications. The FDA and European Medicines Agency have reported a high mortality rate among patients treated with tigecycline in clinical trials

\begin{tabular}{|l|l|}
\hline \multicolumn{2}{|l|}{ Table 4. Antibiotics used in combination with tigecycline } \\
\hline Antibiotic agent & Patients, \% (n) \\
\hline All agents & $45.9 \%(147)$ \\
\hline $\begin{array}{l}\text { Aminoglycosides (Amikacin, Gentamicin, } \\
\text { Netilmicin) }\end{array}$ & $39.4 \%(58)$ \\
\hline Carbapenem (Meropenem, Imipenem) & $22.4 \%(33)$ \\
\hline $\begin{array}{l}\text { Fluoroquinolone (Ciprofloxacin, Levofloxacin, } \\
\text { Moxifloxacin) }\end{array}$ & $5.4 \%(8)$ \\
\hline Piperacillin tazobactam & $2.7 \%(4)$ \\
\hline Glycopeptide (Vancomycin, Teicoplanin) & $6.1 \%(9)$ \\
\hline Colistin & $10.8 \%(16)$ \\
\hline Cefoperazone sulbactam & $0.6 \%(1)$ \\
\hline Linezolid & $3.4 \%(5)$ \\
\hline Metronidazole & $2.7 \%(4)$ \\
\hline Others* & $6.1 \%(9)$ \\
\hline *: Cephalosporins (Cefixime, Ceftriaxone), Sulbactam & \\
\hline
\end{tabular}

$(13,14)$. Due to its benefits and effectiveness, one must consider the risk-benefit ratio for tigecycline use, especially in resistant bacteria. Tigecycline has been used for many indications besides the FDA approved one. Although real life data about its use are limited, some studies involving intensive care patients have suggested promising results with tigecycline treatment $(15,16)$. In this study, ventilatorassociated pneumonia in intensive care patients was one of the most common causes of tigecycline use. The main reason behind this was identification of possibly resistant bacteria, and therefore tigecycline was combined with other antibiotics.

Clinical effectiveness of tigecycline treatment was analyzed with respect to the infection sites. High success rates were found in osteomyelitis, surgical site infections, complicated skin and soft tissue infections, and intraabdominal infections. Even though tigecycline has no approved indication for osteomyelitis, it has demonstrated good bone penetration in previous studies, and has a broad-spectrum activity against nosocomial pathogens, which are a frequent cause of osteomyelitis (17-19). In our study, the success rate of tigecycline treatment was also high in prosthetic joint infections, even though the number of patients of this cause was low. Treatment failure with tigecycline was mostly observed in bloodstream infections, catheter-associated infections, Acinetobacter meningitis and ventilator-associated pneumonia. These findings are also in line with FDA warnings (20).

Tigecycline was generally preferred as monotherapy for skin and soft tissue infections and intra-abdominal infections, and it is mostly initiated as empirical therapy. It was used for targeted treatment and as a part of

\begin{tabular}{|c|c|c|c|c|c|c|c|}
\hline & Total & Empiric & A. baumannii & $\begin{array}{l}\text { Enterococcus } \\
\text { spp. }\end{array}$ & ESBL* & MSS* & MRS* \\
\hline Community-acquired pneumonia & $4.6 \%(15)$ & $100 \%(15)$ & 0 & 0 & 0 & 0 & 0 \\
\hline Hospital-acquired pneumonia & $25 \%(80)$ & $10 \%(8)$ & $86.25 \%(69)$ & 0 & $2.5 \%(2)$ & 0 & $1.2 \%(1)$ \\
\hline Complicated Skin and soft tissue infection & $25 \%(80)$ & $58.8 \%(39)$ & $26.3 \%(21)$ & $3.8 \%(3)$ & $8.8 \%(7)$ & $7.5 \%(6)$ & $5.1 \%(4)$ \\
\hline Intraabdominal infection & $14.7 \%(47)$ & $59.6 \%(28)$ & $10.6 \%(5)$ & $12.8 \%(6)$ & $8.5 \%(4)$ & 0 & 0 \\
\hline Surgical site infection & $10.0 \%(32)$ & $34.4 \%(11)$ & $31.3 \%(10)$ & $9.4 \%(3)$ & $21.9 \%(7)$ & 0 & $3.1 \%(1)$ \\
\hline Urinary tract infection & $9.4 \%(30)$ & $13.3 \%(4)$ & $53.3 \%(16)$ & $16.7 \%(5)$ & $13.3 \%(4)$ & 0 & $3.3 \%(1)$ \\
\hline Intravascular catheter-related infection & $4.4 \%(14)$ & $14.3 \%(2)$ & $535.7 \%(5)$ & $21.4 \%(3)$ & $14.2 \%(2)$ & $14.2 \%(2)$ & 0 \\
\hline Osteomyelitis & $3.8 \%(12)$ & $50.0 \%(6)$ & $41.7 \%(5)$ & $8.3 \%(1)$ & 0 & 0 & 0 \\
\hline Blood stream infection & $1.6 \%(5)$ & 0 & $80.0 \%(4)$ & $20.0 \%(1)$ & 0 & 0 & 0 \\
\hline Meningitis & $0.9 \%(3)$ & 0 & $100.0 \%(3)$ & 0 & 0 & 0 & 0 \\
\hline Prosthetic joint infection & $0.6 \%(2)$ & $50.0 \%(1)$ & $50.0 \%(1)$ & 0 & 0 & 0 & 0 \\
\hline Total & $100 \%(100)$ & $35.6 \%(114)$ & $43.4 \%(139)$ & $6.9 \%(22)$ & $9.4 \%(30)$ & $2.5 \%(8)$ & $2.3 \%(7)$ \\
\hline
\end{tabular}


a combination antibiotic therapy in the remaining unidentified infections. The most common cause of targeted tigecycline use was $A$. baumannii infections.

Tigecycline was usually preferred in combination therapies of $A$. baumannii infections with multi-drug resistance. A. baumannii is a rapidly emerging pathogen that causes nosocomial infections, especially in intensive care units; and multi-drug resistant Acinetobacter infections face treatment difficulties. The rise of carbapenem-resistant $A$. baumanni presents a serious treatment control challenge. Colistin, a relatively old polymyxin drug, and the newer tigecycline, are being used in various antimicrobial combinations for the treatment of this infection (21). In this study, aminoglycosides were the most preferred antibiotics with tigecycline combination, followed by carbapenems.

Treatment change was required in one fourth of patients, $3 \%$ of which were due to unwanted side effects.

The retrospective nature of our study, presenting real life data, is important because there was no intervention in selection of patients. However, the key limitations of this study include absence of any other agent for comparative analysis, and lack of evaluation of any underlying causes that might have affected the treatment failure.

\section{Conclusion}

In the light of the increasing threat to multi-drug resistant infections, with limited treatment options, the use of tigecycline can be concluded to be an effective treatment choice, either as monotherapy or as a combination antibiotic therapy. Its low side effect profile also serves an added advantage. However, one must consider the risk of possible treatment failure in case of severe bacteremia infections.

\section{Authorship Contributions}

Surgical and Medical Practices: F.T., N.E.T., Ş.H., T.I., C.B. Concept: F.T., N.E.T., S.H., T.I., C.B. Design: F.T., N.E.T., S.H., T.I., C.B., F.Ş.E., G.T.E., Ç.A.H., S.K., Data Collection or Processing: F.T., N.E.T., Ş.H., T.I., C.B., F.S..E., G.T.E. Analysis or Interpretation: F.T., N.E.T., S..H., T.I., C.B., Ç.A.H., S.K. Literature Search: F.T., N.E.T., Ş.H., T.I., C.B., F.Ş.E., G.T.E. Writing: F.T., N.E.T.S

Conflict of Interest: No conflict of interest was declared by the authors.

Financial Disclosure: The authors declared that this study received no financial support.

\section{References}

1. Bergeron J, Ammirati M, Danley D, et al. Glycylcyclines bind to the high affinity tetracycline ribosomal binding site and evade Tet(M)-and Tet(O)-mediated ribosomal protection. Antimicrob Agents Chemother 1996;40:2226-8.
2. Projan SJ. Preclinical pharmacology of GAR-936, a novel glycylcycline antibacterial agent. Pharmacotherapy 2000;20:S219-23.

3. Bauer G, Berens C, Projan SJ, et al. Comparison of tetracycline and tigecycline binding to ribosomes map- ped by dimethylsulphate and drug-directed FE2+ clea- vage of $16 \mathrm{~S}$ rRNA. J Antimicrob Chemother 2004;53:592-9.

4. Hoellman DB, Pankuch GA, Jacobs MR, et al. Antipneumococcal activities of GAR-936 (a new glycylcycline) compared to those of nine other agents against penicillinsusceptible and resistant pneumococci, Antimicrob Agents Chemother 2000;44:1085-8.

5. Murphy TM, Deitz JM, Petersen PJ, et al. Therapeutic efficacy of GAR-936, a novel glycylcycline in a rat model of experimental endocarditis, Antimicrob Agents Chemother 2000;44:3022-7.

6. Zhanel GG, Homenuik K, Nichol K, et al. The glycylcyclines: a comparative review with the tetracyclines. Drugs 2004;64:6388.

7. Slover CM, Rodvold KA, Danziger LH. Tigecycline: an ovel broad-spectrum antimicrobial. Ann Pharmacother 2007;41:965-72.

8. Townsend ML, Pound MW, Drew RH. Potential role of tigecycline in the treatment of community-acquired bacterial pneumonia. Infect Drug Resist 2011;4:77-86.

9. Stein GE, Babinchak T. Tigecycline: an update. Diagn Microbiol Infect Dis 2013;75:331-6.

10. Conte JE Jr, Golden JA, Kelly MG, et al. Steady-state serum and intrapulmonary pharmacokinetics and pharmacodynamics of tigecycline. Int J Antimicrob Agents 2005;25:523-9.

11. Babinchak T, Ellis-Grosse $E$, Dartois N, et al. Tigecycline 301 Study Group; Tigecycline 306 Study Group: The efficacy and safety of tigecycline for the treatment of complicated intraabdominal infections: analysis of pooled clinical trial data. Clin Infect Dis 2005;41:S354-67.

12. Ellis-Grosse EJ, Babinchak T, Dartois N, et al. Tigecycline 300 cSSSI Study Group; Tigecycline 305 cSSSI Study Group: The efficacy and safety of tigecycline in the treatment of skin and skin-structure infections: results of 2 double-blind phase 3 comparison studies with vancomycin- aztreonam. Clin Infect Dis 2005;41:S341-53.

13. Europan Medical Agency. Tigecycline. Available from:s URL:http://www.ema.europa. eu/docs/enGB/document library/ EPAR Summary for the public/human/000644/ WC500044509. Accessed January 1, 2014

14. Prasad P, Sun J, Danner RL, et al. Excess deaths associated with tigecycline after approval based on noninferiority trials. Clin Infect Dis 54:1699-709.

15. Curcio D, Vargas SW, Ugarte Ubiergo S, et al. Tigecycline treatment of critically ill patients: the LatinUser experience. Curr Clin Pharmacol 2011;6:18-25.

16. Philippe Montravers Herve' Dupont Jean-Pierre Bedos Philippe Bret The Tigecycline Group. Tigecycline use in critically ill patients: a multicentre prospective observational study in the intensive care setting Intensive Care Med 2014;40:988-97. 
17. Allen T, Griffin A, Julie A, et al. Tigecycline in the management of osteomyelitis: a case series from the bone and joint infection (BAJIO) database. Diag Microb and Infec Dis 2013;77:273-7.

18. Kandemir O, Oztuna V, Colak M, et al. Comparison of the efficacy of tigecycline and teicoplanin in an experimental methicillin-resistant Staphylococcus aureus osteomyelitis model. J Chemother 2008;20:53-7.

19. Seyman DH, Berk, Sepın ON, et al. Successful use of tigecycline for treatment of culture-negative pyogenic vertebral osteomyelitis. Infect Dis (Lond) 2015;47:783-8.
20. FDA Drug Safety Communication: FDA warns of increased risk of death with IV antibacterial Tygacil (tigecycline) and approves new Boxed Warning. Available from:s URL:http:// www.fda.gov/drugs/drugsafety/ucm369580.htm. Accesed April 4, 2016

21. Temocin F, Erdinc FS, Tulek N, et al. Synergistic effects of sulbactam in multi-drug-resistant Acinetobacter baumannii. Braz J Microbiol 2015;46:1119-24. 